UDC 613.64

DOI: 10.21668/health.risk/2017.4.11.eng

\title{
ANALYSIS OF HAZARDOUS WORK ENVIRONMENT FACTORS AT A TRAIN CONDUCTOR WORKPLACE
}

\author{
M.F. Vil'k' , O.S. Yudaeva1, V.A. Aksenov², V.M. Ponomarev², V.I. Apattsev², \\ E.A. Sorokina ${ }^{2}$, V.B. Prostomolotova ${ }^{2}$, A.S. Kozlov ${ }^{2}$, E.O. Latynin ${ }^{1}$ \\ ${ }^{1}$ All-Russian Research Institute of Railway Hygiene, 1, Bldg. 1 Pakgauznoe Shosse Str., Moscow, 125438, \\ Russian Federation \\ ${ }^{2}$ Russian University of Transport (MIIT), 9, Bldg 9 Obrazcova Str., Moscow, 127994, Russian Federation
}

The paper dwells on generalized analysis of morbidity which is characteristic for conductors working in passenger carriages of locomotive-driven trains. Working conditions train conductors had to work in were examined as per results of sanitary-hygienic research on intra-carriage environment, specific working conditions assessment, and questioning. Hazards caused by working environment factors for train conductors to a certain extent depend on a carriage type, its technical and hygienic state, as well as on a route a train goes by.

Our research revealed that impacts exerted by various working environment factors, namely physical, chemical, biological, and psychophysical ones, caused respiratory diseases, increased allergic reactivity, changes in hearing sensitivity, and overall morbidity growth among people from this occupational group.

Unordered regime resulting from constant trips and unfavorable living conditions in a carriage lead to the following diseases: varix dilatation in legs, ischemic heart disease together with primary hypertension, and chronic rheumatic heart diseases. More precise classification of conductors' working conditions can be obtained via a mathematical model creation as it enables precise estimation of occupational diseases probability. Such models should be based on a relationship between diseases frequency (or probability) and working conditions as per specific hygienic factors.

We worked out methodical guidelines on providing safe working conditions at conductors' working places which include efficient activities aimed at prevention of hazardous impacts exerted by working environment factors. It will help to improve working conditions substantially, to preserve workers' health, and to ensure safe passengers traffic.

Safe working conditions for conductors can be secured due to a set of activities aimed at equipping new carriages and those after capital repair with air-conditioning, disinfection systems, heating, ecologically clean toilets, modern furnishing materials, as well as at improving sanitary and living conditions, providing comfortable uniforms, and better regulation of work and rest regimes.

Key words: conductor, passenger carriage, working environment factor, morbidity, sanitary-hygienic research, labor protection.

(C) Vil'k M.F., Yudaeva O.S., Aksenov V.A., Ponomarev V.M., Apattsev V.I., Sorokina E.A., Prostomolotova V.B., Kozlov A.S., Latynin E.O., 2017

Mikhail F. Vil'k - Doctor of Medical Sciences, Professor, Head (e-mail: info@vniijg.ru; tel.: +7 (499) 153-27-37).

Oksana S. Yudaeva - Doctor of Technical Sciences, Associate Professor, leading researcher at Communal Hygiene and Epidemiology Laboratory (e-mail: vniijg@yandex.ru; tel.: +7 (926) 899-73-06)

Vladimir A. Aksenov - Doctor of Technical Sciences, Professor, Head (e-mail: tu@miit.ru; tel.: +7 (495) 799-9559).

Valentin M. Ponomorev - Doctor of Technical Sciences, Professor, Head of "Safety Management in Technosphere" Department (e-mail: elozovskiy@miit.ru; tel.: +7 (985) 9985719). 01).

Vladimir I. Apattsev - Doctor of Technical Sciences, Professor, Head (e-mail: apatsev@rgotups.ru; tel.: +7 (495) 649-19-

Ekaterina A. Sorokina - postgraduate student at "Technosphere Safety" Department (e-mail: pingvin2800@gmail.com; tel.: +7 (916)904-87-54).

Viktoriya B. Prostomolotova - postgraduate student at "Technosphere Safety" Department (e-mail: vikieco@yandex.ru; tel.: +7 (917) 592-01-56).

Aleksandr S. Kozlov - postgraduate student at "Technosphere Safety" Department (e-mail: kozlovas@,rqst.ru; tel.: +7 (985) 777-05-05).

Evgenii O. Latynin - Deputy Director responsible for development (e-mail: jeckkk@rambler.ru; tel.: +7 (916) 624-2996). 
Russian Railways PLC pursues a consistent policy concerning labor protection; the policy is aimed at minimizing risks for occupational injuries and accidents and at maintaining maximum possible safety of all the technological processes in the company.

In 2009 Russian Railways PLC set a technical task to manufacture a range of twostorey passenger carriages for locomotivedriven trains; the main purpose was to implement innovative life support systems, to achieve greater labor productivity of train conductors, to increase constructional speed, to lower life cycle costs per one passengerplace, to decrease energy consumption, and to ensure high social and economic performance figures $[3,13]$.

"On railways rolling stock safety" Customs Union Technical Regulations (TP TC 001/2011) ${ }^{1}$ were based on the RF Federal law "Technical Regulations on fire safety requirements" dated July 22, 2008 No. 123-FL (last edited on July 02, 2013) ${ }^{2}$, these regulations set forth all the requirements to railway rolling stock and its components in order to ensure people's life and health safety. But provision of safety working conditions for train conductors involves working out and updating regulatory-technical and methodological grounds, sanitary-hygienic assessment of environmental factors inside a carriage, and developing recommendations on working conditions improvement.

It is known that carriages costs amount to $20 \%$ of all the railways fixed assets; personnel occupied with passenger carriages maintaining and technical support has approximately the same share among all the railway employees; $60-80 \%$ of this car- riages maintenance staff are women [8].

A train conductor is one of the most widely spread occupations in railway transport; their quantity amounts to approximately 41,000 employees. But still working conditions for these people, both in old and modern carriages, have not been given sufficient attention. Hazard caused by occupational factors for train conductors to a certain extent depends on a carriage type, its technical and hygienic state, as well as on a route a train goes by.

According to the existing data, impacts exerted on workers by physical, chemical, biological, and psychophysical occupational factors cause respiratory diseases, increased allergenic reactivity, changes in auditory sensitivity, and increase in overall morbidity among them. Female workers, beside all that, suffer from disorders in specific female body functions, namely gynecological diseases, and complications during pregnancy and childbirth. A train conductor occupation belongs to a group with the highest occupational risks $[5,6,9,10,12]$. All the above stated proves that a problem of providing safe working conditions for train conductors is truly vital.

As per research data, overall morbidity with temporary disability among train conductors is two times higher than in the branch on average.

Impacts exerted by occupational factors mostly depend on specificity of work tasks a train conductor has to perform as well as on peculiarities of labor organization and working conditions which are characteristic for this occupation only. And here a number of detected adverse occupational factors which exist at conductors' workplaces can't be elim-

\footnotetext{
${ }^{1}$ On railways rolling stock safety: Customs Union Technical Regulations (TP TC 001/2011). Available at: http://webportalsrv.gost.ru/portal/GostNews.nsf/acaf7051ec840948c22571290059c78f/31df4d876b7c282244257a3 7003e01d3/\$FILE/TR_TS_001-2011_text.pdf(07.08.2017).

${ }^{2}$ Federal law dated July 22, 2008 No. 123-FL. Available at: http://docs.cntd.ru/document/902111644 (07.08.2017).
} 
inated directly by any organizational or prevention activities $[7,17]$.

We should note that previous research on conductors' working conditions and morbidity didn't allow for properties of life support systems in up-to-date rolling stock, including two-storey passenger carriages.

Train conductors occupation involves constant travelling, and most conductors have to make long trips lasting from 3 to 7 days.

Experts at Russian Railways PLC perform specialized working conditions assessment as per established procedures in order to provide safe working conditions for train conductors $[1,4,14-16]$.

We can highlight the following basic hazardous and adverse factors related to train conductors occupation: vibration, noise, dustiness, adverse chemicals, luminance, unfavorable microclimate, labor hardness and intensity. Undoubtedly all these adverse occupational factors influence conductors' working conditions and cause their health deterioration $[2,8,18]$.

Experts at Russian Scientific Research Institute for Railway Hygiene conducted research on working conditions and morbidity of passenger carriages conductors. The research results revealed that their morbidity structure had certain peculiarities: conductors mostly suffered from respiratory organs diseases, circulatory system diseases, musculoskeletal system diseases, injuries, and allergy. Those parameters were related not only to age peculiarities of the examined worker but also to specific factors attributable to occupational activities of these railway transport workers.

We also noted that working conditions of passenger carriages conductors involved influence exerted on their bodies by a set of adverse occupational factors, namely overall transport vibration, noise, cooling and heating microclimate, and high neuro-emotional stress. Unfavorable sanitary-hygienic working conditions of train conductors were basically caused by the following: some carriages in operation were not fully equipped with all the necessary components of life support systems; work tasks were not automated enough and had to be performed by hand; carriages interior was not rationally planned and organized; ventilation wasn't efficient; sanitary and communal services were unsatisfactory; labor, rest, and nutrition regimes were not rational.

In 2011 "Tverskoy Carriage Works" PLC started manufacturing various prototypes of two-storey passenger carriages in order to conduct performance tests and to determine sanitary and hygienic standards for them.

Conductors' working conditions were analyzed as per sanitary-hygienic research data and questioning results. Tests were performed in old passenger carriages. Such carriages weren't equipped with air conditioning, water and air disinfection systems, and ecologically clean toilets; finishing and heatinsulating materials in them were of poor quality or even absent; the carriages didn't conform to sanitary-hygienic, toxicological, and fire safety requirements (Figure 1).

There was also comparative research on working environment conditions for train conductors, and their labor hardness and intensity in one-storey old carriages (2002) and two-storey new ones (2013). The research results are given in Figure 2. The results of specific working conditions assessment in the same carriages are shown in Figure 3.

Given all the working environment factors exerting their influence independently, we calculated an aggregated risk level and applied a model incorporating scores of working environment and labor hardness (Figure 4). 


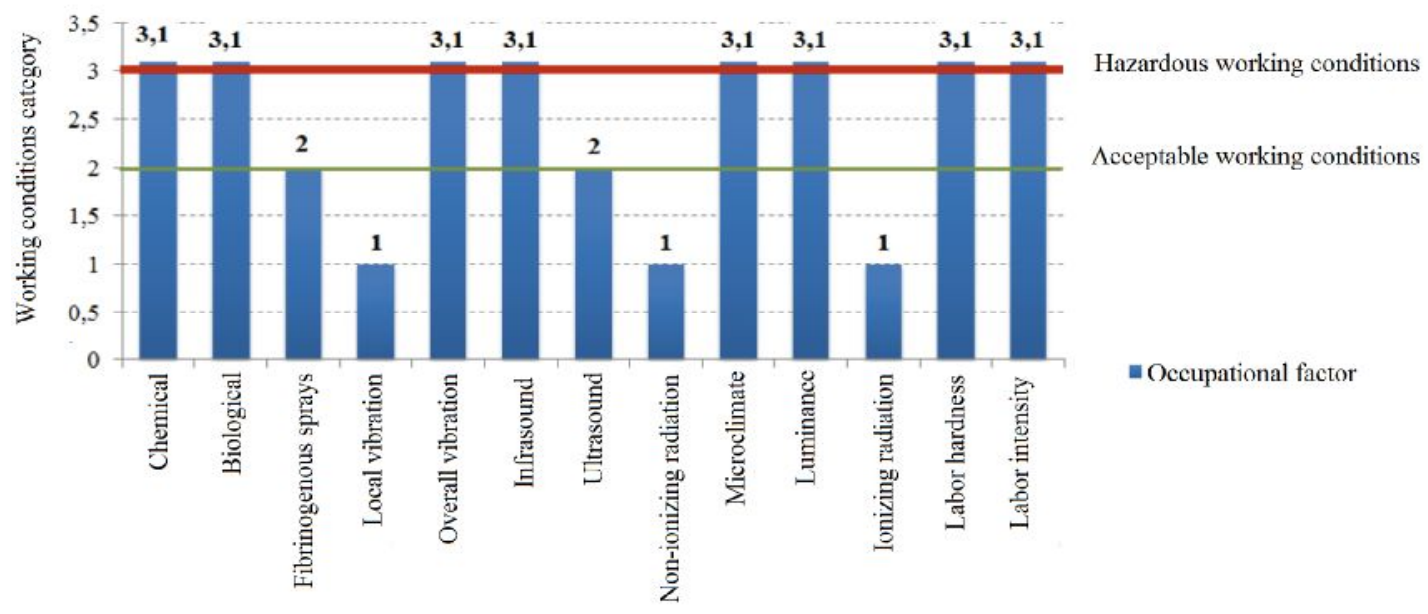

Figure 1. Working conditions at train conductors' workplace: analysis results

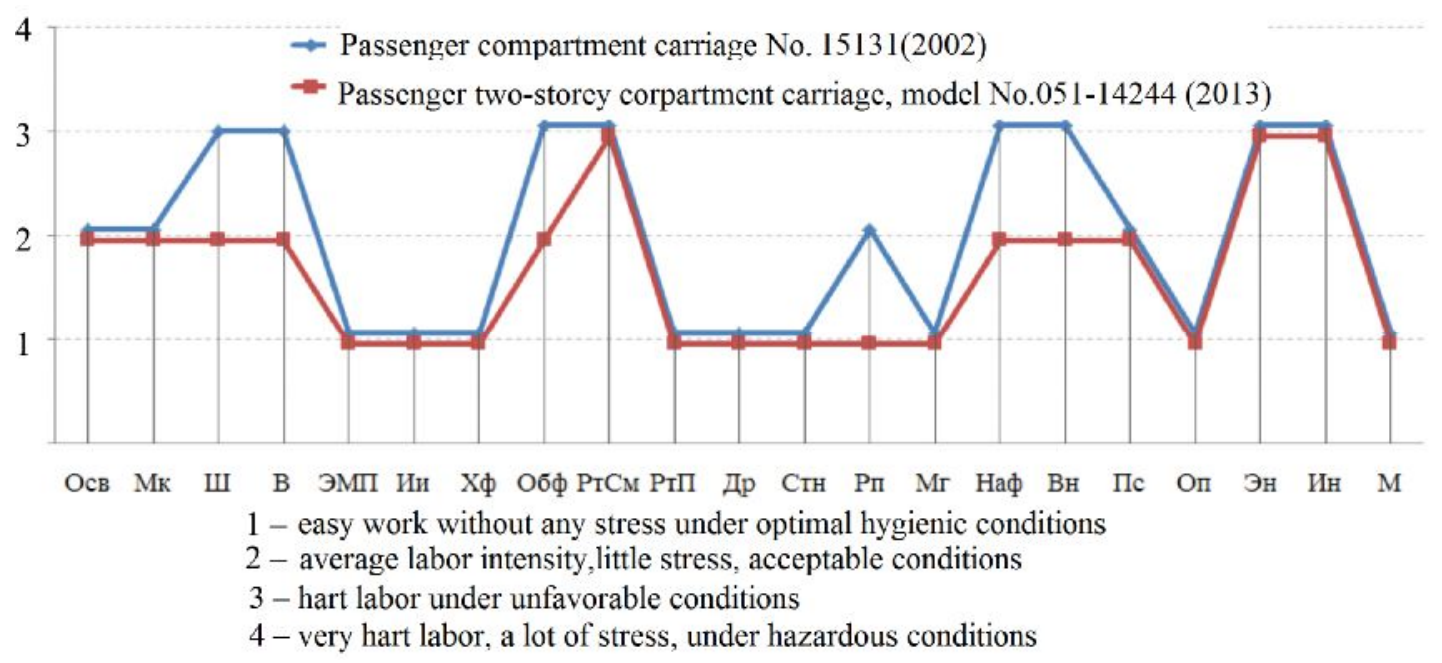

Figure 2. Description of working environment conditions, and labor hardness and intensity for train conductors

Note: here and in Fig. 3 conventions:

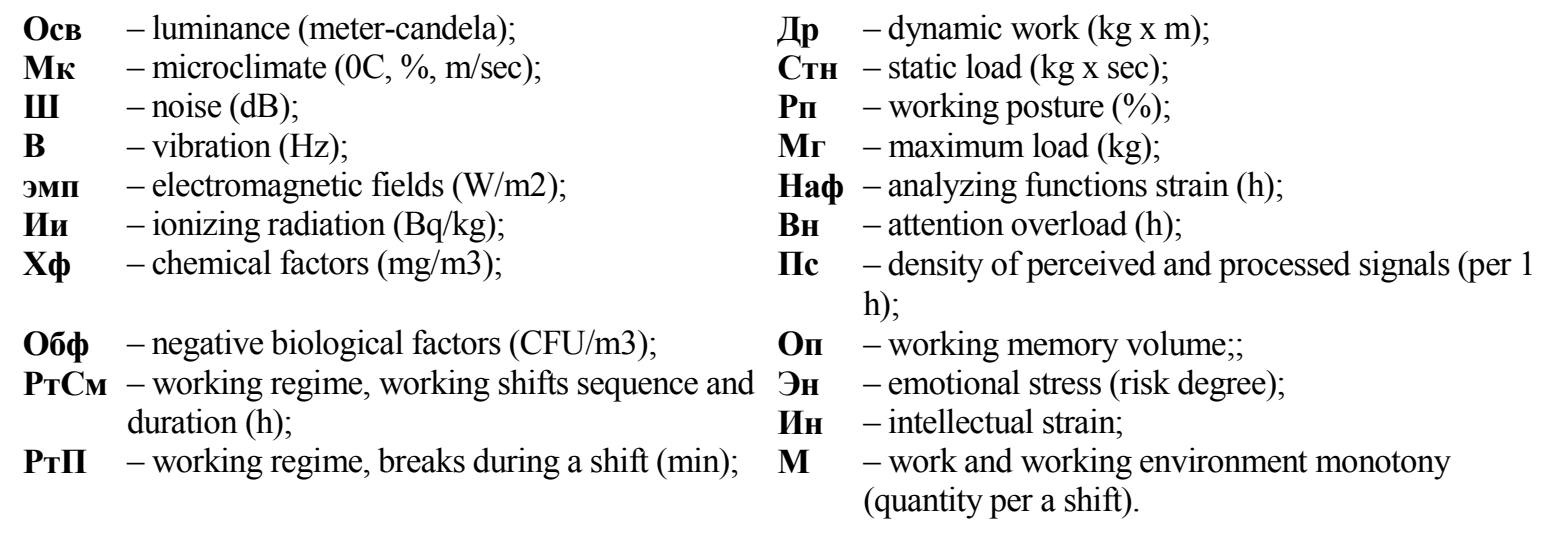




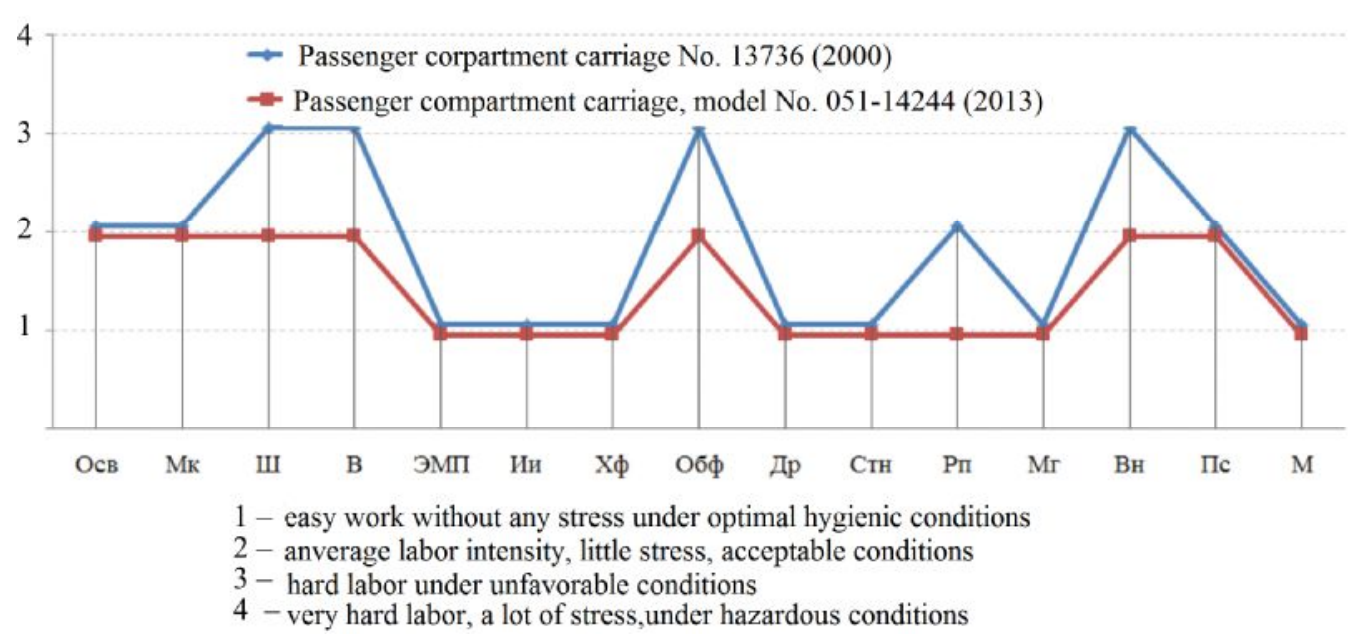

Figure 3. Specific assessment of working conditions for passenger carriages conductors
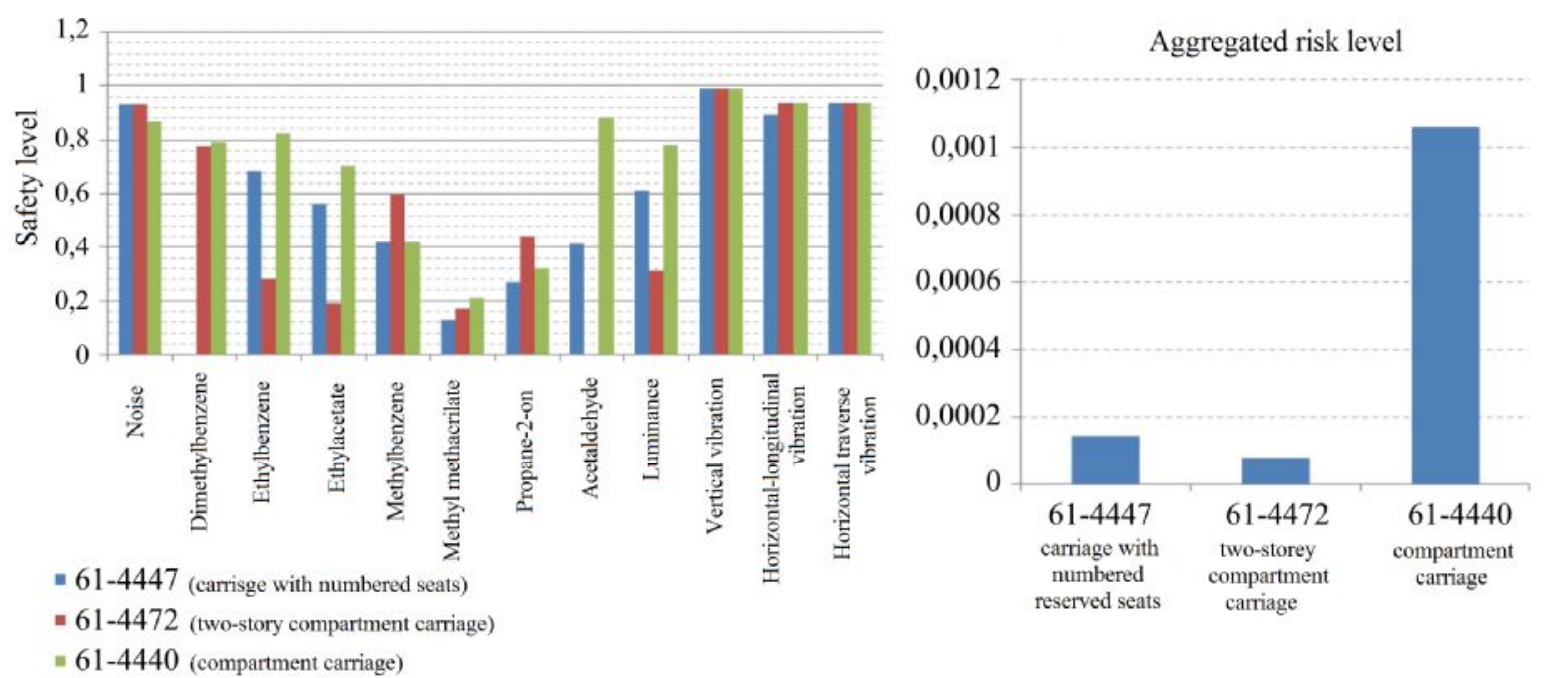

Figure 4. Occupational factors safety for passenger carriages conductors

Though all the scores given to the examined occupational factors correspond to acceptable working conditions category, an aggregated risk level is still rather high. So, the applied calculation model confirms that it is necessary to adopt a complex approach to occupational risk analysis as it allows to assess influence exerted on health simultaneously by several occupational factors.

Our paper also contains an aggregated analysis of passenger carriage conductors morbidity.

Morbidity with temporary disability amounts to 113.1 cases and 1,505.8 days per 100 conductors. Morbidity parameter related to taking care after a sick family member amounts to 13.4 cases per 100 workers; sick leaves related to childbirth are 15.3 cases per 100 workers. Overall morbidity with temporary disability among train conductors is two times higher than the same parameter in the branch as a whole. $89 \%$ of all morbidity cases belong to 7 basic nosologies: respiratory organs diseases, circulatory system diseases, nervous system and sense organs diseases, musculoskeletal system diseases, digestive organs diseases, and injuries.

Respiratory organs diseases among train conductors account for $56 \%$ of all the morbidity cases, and their share is the big- 
gest. Respiratory organs diseases cause more than a half of temporary disability cases; they are mostly acute respiratory diseases, rhinitis, bronchitis, and pneumonia; it is obviously related to influence exerted by hazardous temperature differences, especially during a cold season when train conductors have to exit from a warm carriage onto a platform. It all indicates that working conditions for train conductors need to be improved. Besides, respiratory organs diseases among train conductors cause loss of occupational fitness due to poor health authentically more frequently (by 12.5\%) in comparison with other railway workers. Most frequent diseases here are bronchial asthma and other recurrent bronchial-lungs system diseases caused by high bacterial contamination of the air inside a carriage, various chemicals contents in it, as well as by unfavorable microclimate.

A so called "share of workers who were ill" parameter prevails among train conductors and is equal to $46.8 \%$ (while an average branch one is equal to $40 \%$ only). Besides, a number of workers who have this occupation and can be included into a group of "frequently and long sick people" is also higher than in the branch on average ( $8 \%$ against $6.7 \%$ ).

Results of sociological questioning conducted among this occupational group reveal there are objective conditions and risk factors causing acute and chronic diseases in train conductors:

- influence exerted by a number of working environment factors during roundthe-clock staying inside a carriage (microclimate, noise, vibration, ultrasound, luminance, and chemicals);

- physical loads and significant neuroemotional stress;

- unordered working regime;

- night and day shifts;
- unfavorable sanitary and communal conditions (insufficient motor activity (hypokinesis), constant violation of nutrition, sleep, and rest regimes, absence of possibility to maintain personal hygiene). We also detected that possibilities for physiological and psychological functions recovery were not properly provided and this process organization had a number of drawbacks.

Results of research conducted by A.A. Prokhorov, and V.A. Kudrin [11], which considered conductors' health disorders in view of their occupational activity contain very interesting data on how fast conductors' biological ageing is; the data show that the speed of the process increases greatly at the age from 18 to 27 , and from 38 to 42 . The discrepancy between a true age and a calendar one amounts to 2-3 years during first 10 years of working as a train conductor; when working experience amounts to 16-20 years, this discrepancy grows up to 9 years and remains stable at 3 years when working experience is between 20 and 36 years.

As we studied morbidity structure as per various temporary disability causes taking data from the results of complex medical examinations conducted by experts from Russian Scientific Research Institute for Railway Hygiene, we were able to determine that morbidity among passenger carriages conductors was rather high. It was especially high among people aged 3039 and 40-49.

Respiratory organs diseases (ARVI, angina, laryngitis, tracheitis, and flu) had the greatest specific weight in all age groups.

Rank places in morbidity structure are as follows:

1 rank place belongs to respiratory organs diseases $(56 \%)$;

2 rank place belongs to circulatory system diseases $(6,9 \%)$; 
3 rank place, to musculoskeletal system and connective tissue diseases $(6,6 \%)$;

4 rank place, digestive organs diseases $(4,9 \%)$;

5-6 places are held by skin and subcutaneous tissue diseases, injuries and intoxications $(4,4 \%)$.

We can clearly determine a group of diseases which are closely related to peculiarities of train conductors work in the overall morbidity structure; these diseases are acute respiratory viral infections, flu, angina, nerve plexus diseases, osteoarthritis, radiculitis, stomach and duodenum ulcer, acute gastritis, pyoderma and fungus skin diseases.

Unordered working regime involving a lot of travelling and unfavorable communal conditions in a carriage obviously causes the following diseases: varix dilatation in legs (1.0 case per 100 workers), ischemic heart diseases with primary hypertension (1.1 cases per 100 workers), primary hypertension (4.4 cases per 100 workers), chronic rheumatic heart disease ( 1.1 cases per 100 workers). Skin diseases among train conductors occur 3 times more frequently than in the branch on average.

Circulatory system diseases include the following: primary hypertension, nonrheumatic heart diseases, atherosclerosis, phlebitis, and thrombophlebitis.

Morbidity analysis revealed that nervous system diseases and sense organs diseases occurred among train conductors authentically more frequently than among workers from the comparison group. As for specific nosologies, we detected that conductors more frequently suffered from such diseases as neuritis, neuralgia, inflammatory eyes diseases, and otitis.

We detected that such adverse occupational factors as vibration, dustiness, and neuro-emotional loads, caused disorders in normal adaptation, and activated regulatory mechanisms responsible for specific adaptation and non-specific stress syndrome.

Interesting data with a great practical significance were obtained in the course of research on a group of conductors who had to travel for a long time in different time zones as they went on a train Moscow Vladivostok - Moscow, 14 days overall. They travelled across 6 time zones during their whole trip. Basic age group was 21$33(76 \%$ of the examined workers), prevailing working experience was equal to 15 years $(69 \%)$. All the examined workers were practically healthy but before their trip they complained on considerable fatigability, tiredness, and low working capacity. Such complaints grew stronger after a trip. Besides, after a trip conductors also complained on sleep disorders related both to sleep and wake regime violations (night shifts) and to different time zones and break of daily biorhythms. Closer to an end of a trip eastward they had difficulty in falling asleep, or they fell asleep too fast and woke after a very short sleep (only 1-2 hours). Sleep didn't help to get needed rest and to recover psychological and physical working capacity. All the data on train conductors state before and after a trip revealed that long-term trips in equatorial direction exerted considerable negative influence on a body which caused substantial decrease in its adaptive abilities, antimicrobe protection, and anti-oxidant state; it all could eventually lead to various infectious and non-infectious diseases occurrence.

More than a half of all the questioned conductors were 40-50 years old. As per statistic data, in 2007 30-40 age group prevailed, and we can state that workers' average age grew. Duration of working experience as "passenger carriage conductor" also increased considerably: in $200745 \%$ 
workers had working experience equal to 10 and more years; in 2014 share of such workers grew up to $57 \%$. Such parameters as overall morbidity, and a share of workers who were sick among conductors, correlate with workers' age and working experience; therefore, such a trend can lead to growth in morbidity cases among workers.

Working experience in up-to-date rolling stock generally is not longer than 3 years ( $47 \%$ of the questioned).

Female conductors amounted to $72 \%$, and it was lower than in 2007 (83\%); still, a share of female workers among train conductors remains substantially high.

Workers gave their own assessment of how often they were sick: $47 \%$ on average 1 time a year; $26 \%$ were rarely sick; $24 \%$ were sick 2-3 times a year; $3 \%$, more than 5 times a year. A mathematical model can help to obtain more precise classification of conductors' working conditions; such a model precisely assesses occupational diseases probability. The model is based on a relationship between diseases frequency (or probability) and labor situation as per specific hygienic factors.

So, to sum up results of our work dedicated to analyzing functional and physiological peculiarities, state of a body, and occupational activities of train conductors, we should point out that we revealed grave strain in background parameters of psychophysiological functions used in conductors' occupational activities, as well as adaptation-compensatory reactions violation; all this makes health disorders among this occupational group much more probable. Data obtained by a number of researchers prove there is neuro-emotional stress in conductors, especially during long trips.

We can say that all the obtained data undeniably prove occupational causality of morbidity with temporary disability among passenger carriages conductors.

The performed analysis revealed that overall morbidity among train conductors was growing. But passenger carriages conductors who were younger than 50 fell sick less frequently in comparison with other occupational groups; morbidity escalated only among people older than 50 .

In the course of our research we developed a set of priority measures aimed at providing safe working conditions for train conductors (Figure 5). The suggested system should help to solve vital tasks on hygienic optimization and passenger transportation safety, occupational environment improvement, prevention of morbidity among passenger carriages conductors; today, it can be taken as a generic one in labor protection activities in passenger transportation sphere.

We developed methodical recommendations on providing safe working conditions at train conductors' workplaces; they include efficient activities aimed at prevention of unfavorable influence exerted by adverse occupational factors and will allow to improve working conditions considerably, to preserve health, and to provide safety (Figure 6). A set of measures was implemented in equipping new carriages and carriages after capital repair; the carriages were equipped with air-conditioning units, disinfection units, heating, ecologically clean toilets; up-to-date finishing materials were applied during repairing; sanitary and communal conditions in the carriages were improved. Conductors were provided with comfortable uniforms, their rest and work regimes were better regulated; all the above-mentioned helped to provide working conditions with 2 nd hazard degree (acceptable ones) additionally for $22 \%$ conductors over the last 5 years. 


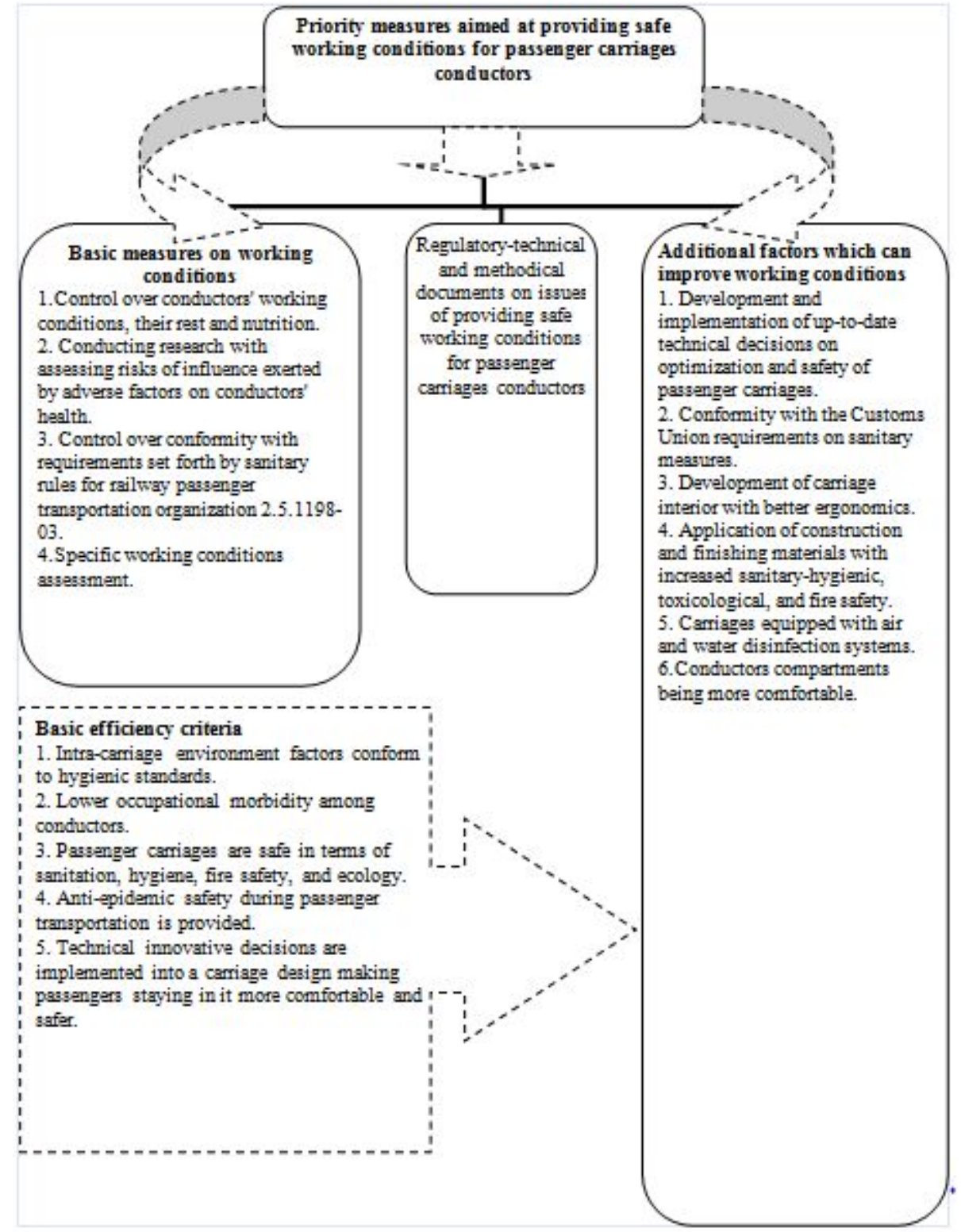

Figure 5. A set of priority measures aimed at providing safe working conditions for passenger carriages conductors

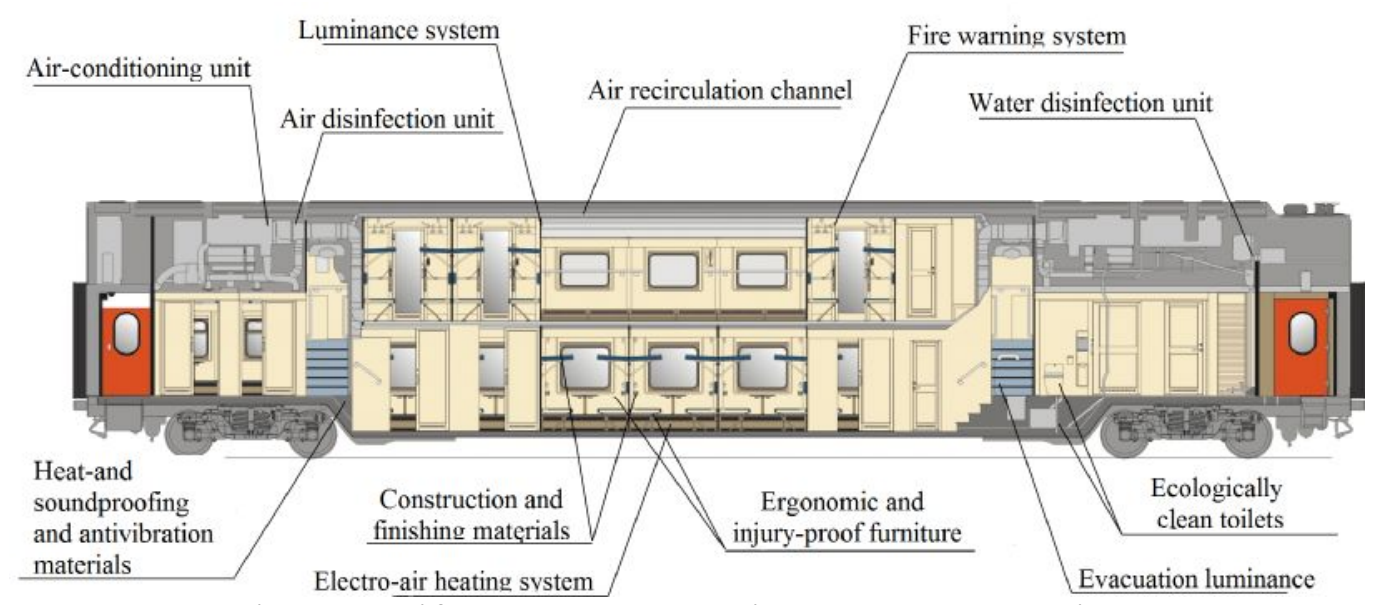

Figure 6. Life support systems in a two-storey carriage 


\section{References}

1. Belyakov G.I. Okhrana truda [Labor protection]. Moscow, Yurait, Publ., 2013, 572 p. (in Russian).

2. Gigiena truda [Occupational hygiene].In: N.F. Izmerov, V.F. Kirillov, eds. Moscow, GEOTAR-Media, Publ., 2008, 592 p. (in Russian).

3. Saikin A.M., Ryabchikov O.B., Yudaeva O.S., Zaikov G.E. K otsenke ekologichnosti i pozharobezopasnosti polimersoderzhashchikh materialov inter'era ATS [An assessment of ecological and fire safety of polymer-containing materials into vehicle interior]. Trudy NAMI, 2012, no. 248, pp.78-91(in Russian).

4. Klochkova E.A. Okhrana truda na zheleznodorozhnom transporte [Labor protection at railroad transport]. Moscow, Marshrut, Publ., 2004, 412 p. (in Russian).

5. Kommunal'naya gigiena [Communal hygiene]. In: V.T. Mazaev, ed. Moscow, GEOTAR-Media, Publ., 2005, part 2, 304 p. (in Russian).

6. Mel'nichenko P.I., Prokhorov N.I., Arkhangel'skii V.I. Obshchaya gigiena, sotsial'nogigienicheskii monitoring: rukovodstvo k prakticheskim zanyatiyam. Razdel «Obshchaya gigiena» [Common hygiene, social-hygienic monitoring: practical studies guide. "Common hygiene" section]. Moscow, Prakticheskaya meditsina, Publ., 2014, 332 p. (in Russian).

7. Ponomarev V.M., Ul'yanov V.A. Vliyanie motivatsii truda na povyshenie bezopasnosti proizvodstvennoi deyatel'nosti personala [Influence exerted by labor motivation on increasing safety of staff production activities]. Nauka i tekhnika transporta, 2012, no. 2, pp. 106-112 (in Russian).

8. Potapov A.I, Titova T.S. Ekologicheski bezopasnye tekhnologii na zheleznodorozhnom transporte [Environmentally safe technologies in railway transport]. Transport Rossiiskoi Federatsii, 2010, vol. 31, no. 6, pp. 72-77 (in Russian).

9. Professional'nye zabolevaniya: rukovodstvo [Occupational diseases: Guide]. In: N.F. Izmerov, ed. Moscow, Meditsina, Publ., 1996, vol. 1, 336 p. (in Russian).

10. Professional'nye zabolevaniya: rukovodstvo [Occupational diseases: Guide]. In: N.F. Izmerov, ed. Moscow, Meditsina, Publ., 1996, vol. 2, 480 p. (in Russian).

11. Prokhorov A.A., Kudrin V.A. Okhrana zdorov'ya rabotnikov lokomotivnykh brigad I obespechenie bezopasnosti dvizheniya poezdov na zheleznykh dorogakh: rukovodstvo [Protecting health of locomotive teams and providing railroad traffic safety: Guide]. Moscow, VNIIZhG MPS Rossii, Publ., 2000, 107 p. (in Russian).

12. Rossol'ko D.S. Osobennosti trudovoi deyatel'nosti i sostoyanie reproduktivnogo zdorov'ya zhenshchin-provodnikov zheleznodorozhnogo transporta: avtoref. dis.. kand. med. Nauk [Working activities peculiarities and reproductive health of female conductors at railroad transport: abstracts of a candidate's dissertation]. Sankt-Peterburg, 2005, 20 p. (in Russian).

13. SP 2.5.1198-03. Sanitarnye pravila po organizatsii passazhirskikh perevozok na zheleznodorozhnom transporte. Utv. Glavnym gosudarstvennym sanitarnym vrachom Rossiiskoi Federatsii [Sanitary rules for passenger traffic on railroad. Approved by the RF Chief State Sanitary Inspector]. 2003. Available at: https://ohranatruda.ru/ot_biblio/norma/249197/ (30.07.2017) (in Russian).

14. STO RZhD 1.15.003-2008. Proizvodstvennyi kontrol' uslovii truda v OAO «RZhD»: standart OAO «RZhD» [STORR 1.15.003-2008. Industrial surveillance over working conditions in Russian Railways PLC RR PLC Standard]. Available at: www.ttgdt.edu.ru/students/railway/sto/sto\%20rzd\%201.15.003-2008.pdf (08.08.2017) (in Russian).

15. STO RZhD 15.012-2014. Sistema upravleniya okhranoi truda v OAO «RZhD». Spetsial'naya otsenka uslovii truda: standart OAO «RZhD» [STORR 15.012-2014. Labor protection 
system in RR PLC. Specific assessment of working: PLC RR PLC Standard]. Available at: www.dorprof-kbsh.ru/wp-content/uploads/S-STO-RZhD-15.012-2014-SUOT.doc (08.08.2017) (in Russian).

16. STO RZhD 15.014-2012. Sistema upravleniya okhranoi truda v OAO «RZhD». Organizatsiya kontrolya i poryadok ego provedeniya: standart OAO «RZhD» [STORR 15.014-2012. Labor protection system in RR PLC. How surveillance is organized and performed: PLC RR PLC Standard]. Available at: http://docs.cntd.ru/document/1200102122 (08.08.2017) (in Russian).

17. Ul'yanov V.A. Analiz avariinosti i proizvodstvennogo travmatizma na OPO i faktory, vliyayushchie na sostoyanie bezopasnosti truda personala [Analysis of accidence and occupational traumatism at hazardous industrial objects and factors influencing staff labor safety]. Chelovek i trud, 2012, no. 6, pp. 47-51(in Russian).

18. Vil'k M.F., Ovechkina Zh.V., Sosnova T.L., Yudaeva O.S., Bukhareva E.A. Uchityvat' potrebnosti i osobennosti vsekh kategorii invalidov [To allow for needs and peculiarities of all disabled people]. Zheleznodorozhnyi transport, 2011, no. 6, pp. 30-31(in Russian).

Vil'k M.F., Yudaeva O.S., Aksenov V.A., Ponomarev V.M., Apattsev V.I., Sorokina E.A., Prostomolotova V.B., Kozlov A.S., Latynin E.O. Analysis of hazardous work environment factors at a train conductor workplace. Health Risk Analysis, 2017, no. 4, pp. 97-107. DOI: 10.21668/health.risk/2017.4.11.eng

Received: 14.09.2017

Accepted: 19.12.2017

Published: 30.12 .2017 